\title{
Comparative Effects of Basalt Dust, NPK 20-10-10 and Poultry Manure on Soil Fertility and Cucumber (Cucumis sativus) Productivity in Bafut (Cameroon Volcanic Line)
}

\author{
Primus Azinwi Tamfuh ${ }^{1,2, *}$, Pierre Wotchoko ${ }^{3}$, Djibril Gus Kouankap Nono ${ }^{3}$, \\ Carine Naah Yuh Ndofor ${ }^{3}$, David Guimolaire Nkouathio ${ }^{4}$, Dieudonné Bitom ${ }^{1}$ \\ ${ }^{1}$ Department of Soil Science, Faculty of Agronomy and Agricultural Sciences, University of Dschang, Dschang, Cameroon \\ ${ }^{2}$ Department of Mining and Mineral Engineering, National Higher Polytechnic Institute, University of Bamenda, Bambili, Cameroon \\ ${ }^{3}$ Department of Geology, Higher Teacher Training College, University of Bamenda, Bambili, Cameroon \\ ${ }^{4}$ Department of Earth Sciences, Faculty of Sciences, University of Dschang, Dschang, Cameroon
}

\section{Email address:}

aprimus20@yahoo.co.uk (P. A. Tamfuh), pierrewotchoko@yahoo.fr (P. Wotchoko), kouankap@yahoo.fr (D. G. K. Nono), carinefield@yahoo.com (C. N. Y. Ndofor),nkouathio@yahoo.fr (D. G. Nkouathio), bitomoyono@yahoo.fr (D. Bitom)

${ }^{*}$ Corresponding author

\section{To cite this article:}

Primus Azinwi Tamfuh, Pierre Wotchoko, Djibril Gus Kouankap Nono, Carine Naah Yuh Ndofor, David Guymollaire Nkouathio, Dieudonné Bitom. Comparative Effects of Basalt Dust, NPK 20-10-10 and Poultry Manure on Soil Fertility and Cucumber (Cucumis sativus) Productivity in Bafut (Cameroon Volcanic Line). Earth Sciences. Vol. 8, No. 6, 2019, pp. 323-334. doi: 10.11648/j.earth.20190806.13

Received: October 19, 2019; Accepted: November 12, 2019; Published: November 19, 2019

\begin{abstract}
Although chemical fertilizers have boosted food production in the last century, their efficiency is limited by their low potential to remineralize and restore chemically depleted soils at long term. This work investigates the comparative effects of basalt dust, poultry manure and NPK 20-10-10 on soil fertility and cucumber performance in Bafut (North-West Cameroon). The work was done in the field and in the laboratory. The experimental plot $\left(82 \mathrm{~m}^{2}\right)$ was a randomized complete block design (RCBD) with five treatments (and three replications): control $\left(\mathrm{T}_{0}\right), 2.5$ tons ha ${ }^{-1}$ of basalt dust (T1), 20 tons $\mathrm{ha}^{-1}$ of poultry manure $\left(\mathrm{T}_{2}\right), 0.7$ tons $^{-1} \mathrm{~h}^{-1}$ of NPK 20-10-10 fertilizer $\left(\mathrm{T}_{3}\right)$ and 5 tons ha ${ }^{-1}$ of basalt dust $\left(\mathrm{T}_{4}\right)$. The main results revealed that $\mathrm{T}_{0}$ showed a sandy clayey loam texture, acidic $\mathrm{pH}(5.1)$, very high organic carbon $(6.4 \%)$, low total nitrogen $(0.2 \%)$ and moderately available phosphorus $\left(16.70 \mathrm{mg} \mathrm{kg}^{-1}\right)$. The exchangeable complex revealed high $\mathrm{K}\left(1.02 \mathrm{cmol}(+) . \mathrm{kg}^{-1}\right)$, very low $\mathrm{Ca}\left(0.45 \mathrm{cmol}(+) . \mathrm{kg}^{-1}\right)$ and $\mathrm{Mg}^{2+}(0.17 \mathrm{cmol}(+)$. $\left.\mathrm{kg}^{-1}\right)$, low $\mathrm{Na}^{+}\left(0.2 \mathrm{cmol}(+) . \mathrm{kg}^{-1}\right)$, very low sum of exchangeable bases $\left(1.84 \mathrm{cmol}(+) . \mathrm{kg}^{-1}\right)$, very low cation exchange capacity (CEC) and a moderate base saturation (43.4\%). The $\mathrm{C} / \mathrm{N}$ was very high (23) indicating very poor quality organic matter and a potentially very slow mineralization rate. After treatment, $\mathrm{pH}$, exchangeable bases $\mathrm{Ca}$ and $\mathrm{Mg}$ increased after harvest whereas $\mathrm{Na}$ and $\mathrm{K}$ decreased for all the treatments. The growth and yield parameters of all treatments, except number of fruits, were such that $\mathrm{T}_{2}>\mathrm{T}_{3}>\mathrm{T}_{4}>\mathrm{T}_{1}>\mathrm{T}_{0}$. The numbers of fruits were as follows: $\mathrm{T}_{2}>\mathrm{T}_{4}>\mathrm{T}_{3}>\mathrm{T}_{1}>\mathrm{T}_{0}$. The most economically viable soil treatment was attained by $\mathrm{T}_{2}$ with a profit rate (PR) of $933 \%$ and a VCR value of 10.3 . Treatments $T_{1}, T_{2}, T_{3}$ and $T_{4}$ were all profitable since their value-to cost ratio (VCR) $>1$, but only $T_{2}$ and $T_{3}$ show a VCR (value-to-cost ratio) greater than 2 and are thus recommended for popularization.
\end{abstract}

Keywords: Basalt Dust, Crop Production, Cucumber, Soil Remineralisation, Bafut, Cameroon Volcanic Line

\section{Introduction}

Soil remineralisation is the replenishment of nutrients in depleted soils through the application of rock dusts [1]. It is based on the fact that continuous crop cultivation depletes soil nutrients [2]. Remineralization improves the capacity to release essential nutrients to plants [3]. Results of soil remineralization led to $150 \%$ yield improvement and nutritional value increase of crops due to primary and long term beneficial effects of rock dusts [4]. The effect of rock dust on plant growth is of importance in biologically 
orientated agriculture $[5,6]$. This enables recent developments in the use of rock dust to be described as "Stone Age" farming [7]. Yeomans [3] reports the potential of remineralization to lower global atmospheric $\mathrm{CO}_{2}$ levels to safe levels, revitalize soil and biological life as well as increase human nutrition and health levels. In Cameroon, [8-12] applied various rock dusts as fertilizers and concluded on their gradual, continuous and long-term nutrient release to soils and recommended volcanic rocks from the Cameroon Volcanic Line (CVL) for soil remineralization. A survey from farmers in Bafut Sub- division has revealed that although the Bafut soils are very humiferous, they often give poor yields even upon application of chemical fertilizers. This work was aimed at testing basalt dust and comparing its effects to those of poultry manure and NPK fertilizers on soil fertility and Cucumber productivity. The results obtained will serve as a benchmark for the use of natural rock fertilizers for remineralization of degraded soils. The benefits are both environmental to cub the use of chemical fertilizers and economical to reduce cost of chemical fertilizer importation.

\section{Materials and Methods}

\subsection{Study Site Description}

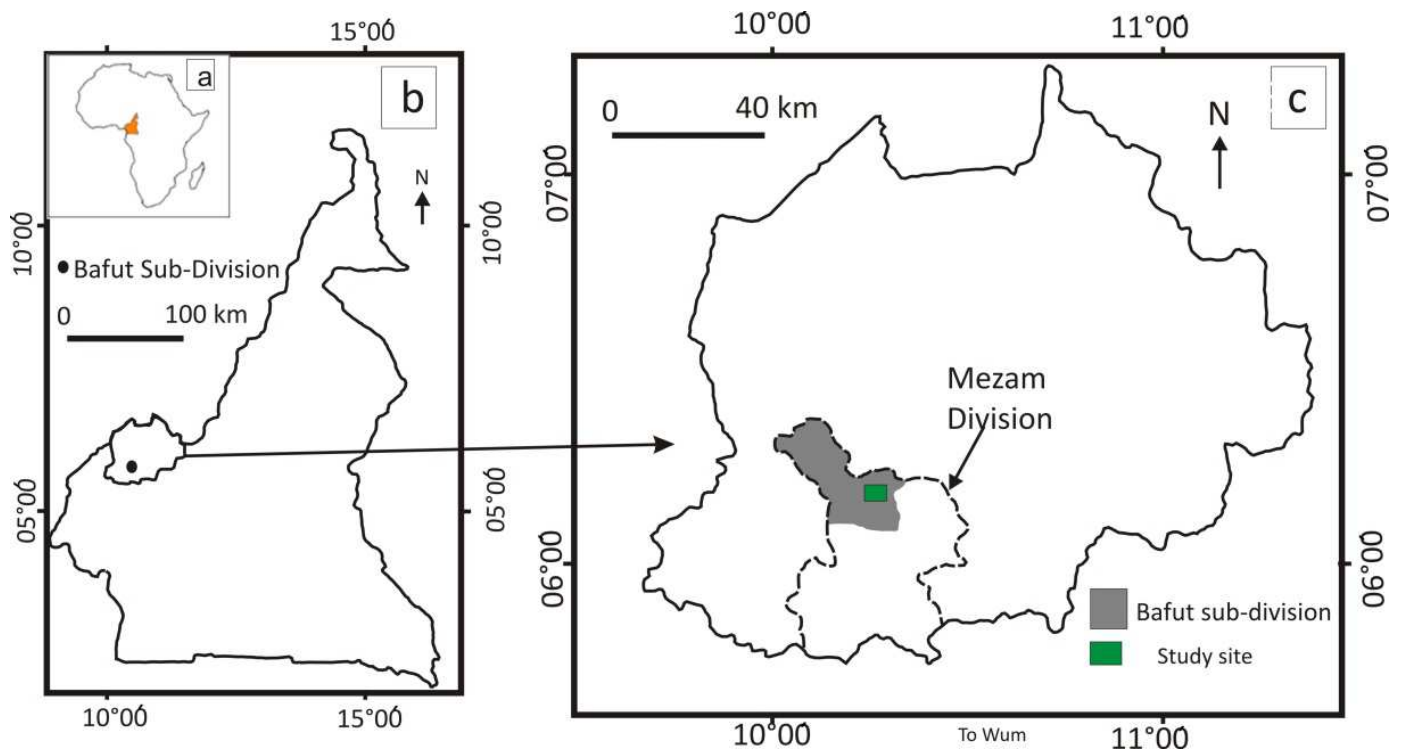

Figure 1. Location map showing: a) the location of Cameroon in Africa; b) the location of the North West region in the Cameroon map; c) the location of the studied site in Bafut Sub-division, Mezam Division and in the North West Region.

Bafut Sub-Division is located in Mezam Division in the North West Region of Cameroon (Figure 1). Bafut is located in the South East of Mount Bamenda that rises at $2621 \mathrm{~m}$ altitude [13]. The climate of the area is the Cameroon type equatorial climate, with two seasons (a rainy season of eight months from mid-March to mid-November) and a dry season of four months (mid-November to mid-March) [14]. The total annual rainfall is $2372 \mathrm{~mm}$ and the mean annual temperature is $25^{\circ} \mathrm{C}$. The study site, Njimbee, is located in the East of Bafut, between latitude $10^{\circ} 05^{\prime \prime} 00^{\prime \prime}$ to $10^{\circ}$ 12 " 00 "E and latitudes $05^{\circ} 55^{\prime \prime} 00$ " to $05^{\circ} 62^{\prime \prime} 00^{\prime \prime} \mathrm{N}$. Njimbee is more or less on a plain and the highest altitude is at $1400 \mathrm{~m}$. It has a sub dendritic drainage system with all streams flowing into the Mezam River (main drainage basin of the area). The area belongs to the tropical grasslands, dominated by palm bushes and eucalyptus meanwhile the raffia bushes are limited to swampy valleys. This natural vegetation is strongly modified by human activities [15]. The area is covered by granitic rocks that overlie the granite-gneissic basement. The dominant soils within the study area the red ferrallitic soils with dark surface horizons, meanwhile hydromorphic soils are found in the swampy valleys [16]. The main activity of the population is farming, but few inhabitants practice small scale business.

\subsection{Field and Laboratory Methodology}

A plot of $81 \mathrm{~m}^{2}$ was cleared and tilled. It was divided into three blocks and each block further sub-divided into five ridges or experimental units (EU). The ridges were $6 \mathrm{~m}$ long and $0.9 \mathrm{~m}$ wide with a furrow of $0.4 \mathrm{~m}$. The experimental layout was a randomized complete Block Design. Five treatments were applied with three replications: control $\left(\mathrm{T}_{0}\right)$, 2.5 tons $\mathrm{ha}^{-1}$ of basalt dust $\left(\mathrm{T}_{1}\right), 20$ tons $\mathrm{ha}^{-1}$ of poultry manure $\left(\mathrm{T}_{2}\right), 0.7$ tons $\mathrm{ha}^{-1}$ of NPK 20-10-10 fertilizer $\left(\mathrm{T}_{3}\right)$ and 5 tons $\mathrm{ha}^{-1}$ of basalt dust $\left(\mathrm{T}_{4}\right)$. Five holes of $5 \mathrm{~cm}$ depth and $10 \mathrm{~cm}$ diameter were dug on each ridge. Basalt dust was put into these holes, mixed with soil and covered. This was done on the $8^{\text {th }}$ of August 2017. On the $30^{\text {th }}$ of August 2017 similar holes were made on the ridges but this time filled with poultry manure. The planting was done on the $2^{\text {nd }}$ of September 2017. Experimental units were directly seeded at a depth of $2.5 \mathrm{~cm}$ with two seeds per hole. The plant 
germinated four days prior to sowing and NPK 20-10-10 was applied 10 days after planting on the ridges meant for this treatment. The NPK 20-10-10 fertilizer was applied by making a small circle round the plant with a radius of $7 \mathrm{~cm}$ to avoid direct contact with the plant. Weeding and mulching was done every 3 weeks to keep the experimental units free from weeds and to keep the soil porous.

\subsection{Soil Sampling and Laboratory Analysis}

Prior to land preparation, five soil samples were randomly collected in the experimental plot between 0 and $25 \mathrm{~cm}$ depth, mixed thoroughly to form a composite sample, stored in a clean plastic bag and sent to the laboratory for analysis. In the laboratory, the soil sample was air-dried for one week. Afterwards, it was crushed in an agate mortar into fine powder and passed through a $2 \mathrm{~mm}$ sieve then stored in a glass container under ambient conditions pending analysis. The results of this composite sample (control soil) enabled to perform a land evaluation and to determine the degree of limitation before administering the different treatments. After harvest, composite samples were collected for each treatment and used to assess the effect of the various treatments on the soil characteristics and the crop performance. The rock samples for thin section cutting were collected in Njimbee-Bafut. Also, basalt samples used for soil amendment were collected in a quarry in Sabga $(6 \mathrm{~km}$ East of Bafut Sub-Division).

\subsection{Plant Data Collection}

The data collection started one week prior the application of NPK 20-10-10 that is the $23^{\text {rd }}$ of September 2017. The measurements were taken every two weeks for four months. The mean growth parameters (germination rate, number of leaves, plant height, stem diameter, leaf length and leaf diameter) and mean yield parameters (number of fruits, fruit length, fruit diameter and fruits weight) were measured for 5 plants per EU.

\subsection{Laboratory Analysis}

Rock petrographic and soil physico-chemical analyses were conducted in the laboratory. The Petrographic analysis involved the cutting of rock thin sections (basalt and granite) at the Institute of Geologic and Mining Research (IRGM) in Yaoundé (Cameroon). Microscopic observations were done in the Geology Laboratory of the University of Bamenda. The soil physico-chemical analyses were done at the "Laboratory of Soil Analysis and Chemistry of the Environment"(LABASCE) of the University of Dschang (Cameroon). The bulk density was determined by paraffin coating method and particle density was measured by pycnometer method [17]. Soil porosity was deduced from bulk density and particle density [17]. The particle size distribution was measured by Robinson's pipette method [17]. The $\mathrm{pH}-\mathrm{H}_{2} \mathrm{O}$ was determined in a soil/water ratio of $1: 2.5$ and $\mathrm{pHKCl}$ was measured in a soil/ $\mathrm{KCl}$ ratio of $1: 2.5$ [17]. The organic carbon (OC) was measured by WalkleyBlack method [18]. The total nitrogen (TN) was measured by the Kjeldahl method [19]. Available phosphorus was determined by concentrated nitric acid reduction method [20]. Exchangeable cations were analyzed by ammonium acetate extraction at $\mathrm{pH} 7$ [21]. The CEC was measured by sodium saturation method [22]. The base saturation was calculated as the percentage of the sum of exchangeable cations (S) divided by the cations exchange capacity [23].

\subsection{Land and Climate Evaluation}

Land evaluation was intended to evaluate climate and land suitability for beetroot cultivation. The climatic index (CI) was obtained by the square root formula of [24]:

$$
\mathrm{IC}=\mathrm{R}_{\min }(\mathrm{A} / 100 \times \mathrm{B} / 100 \ldots)^{1 / 2}
$$

where $R_{\min }$ is the lowest parametric value of all groups and $\mathrm{A}, \mathrm{B}, \ldots$...tc is the remaining parametric values. The parametric value of climate or climatic rating (CR) was obtained by the conversion of the CI according to [24]:

$$
\begin{gathered}
\text { If } 25<\mathrm{CI}<92.5 \ldots \ldots \mathrm{CR}=16.67+0.9 \times \mathrm{C} \\
\text { If } \mathrm{CI}<25 \ldots \ldots \mathrm{CR}=1.6 \times \mathrm{IC}
\end{gathered}
$$

The limitation approach was used for land evaluation. Limitations are deviations from the optimal conditions of a land characteristic/land quality which adversely affect a kind of land use. If a land characteristic is optimal for plant growth, it has no limitations. On the other hand, when the same characteristic is unfavourable, it has severe limitations. The final assessment was performed by calculating the earth index (IT) which combines climatic and soil characteristics according to [24]:

$$
\mathrm{IT}=\mathrm{R}_{\min }(\mathrm{A} / 100 \times \mathrm{B} / 100 \times \ldots)^{1 / 2}
$$

where IT is the Earth Index, $\mathrm{R}_{\min }$ is the lowest parametric value and $\mathrm{A}, \mathrm{B} \ldots$... etc are the other parametric values. The IT value obtained was corrected to the corrected earth index (ITc) as:

$$
\begin{aligned}
& \text { If } 0<\text { IT } \leq 25 \ldots . . \text { ITc }=\text { IT } \\
& \text { If } 25<\text { IT } \leq 50 \ldots \ldots \text { ITc }=25+(\text { IT-5 }) \times 0.455 \\
& \text { If } 50<\text { IT } \leq 75 \ldots \ldots . \text { ITc }=50+(\text { IT }-5) \times 0.41 \\
& \text { If } 75<\text { IT } \leq 100 \ldots . . \text { ITc }=50+(\text { IT }-60) \times 0.625
\end{aligned}
$$

Suitability classes were defined based on ITc [25].

\subsection{Data Analysis}

Statistical analysis was performed using the SPSS software program (SPSS Inc., Version 12.0). The data were analyzed by one-way analysis of variance (ANOVA). The Tukey's test was used to detect the statistical significant differences $(\mathrm{P}<0.05)$ between means.

\subsection{Economic Analysis}

In order to test the economic viability each soil treatments, the 
yields were subjected to economic evaluation according to [26]. Thus, mean yields, mean costs and unit price per $\mathrm{kg}$ of each treatment were used. Net profit (NP), marginal net return (MNR), value-to-cost ratio (VRC), and marginal rate of return or profit rate (MRR or PR) were calculated. For a $\mathrm{VRC}>1$, profit is expected, but if $\mathrm{VRC}<1$, no profit is expected. Nevertheless, for a $V R C \geq 2$, at least $100 \%$ profit rate of the total investment is expected and the fertilizer (treatment) is worth popularizing. The gross benefit (GB) of a fertilizer treatment is obtained by multiplying the yield per treatment by the field price per $\mathrm{kg}$ of cucumber. The operation cost (OC) on the other hand is comprised of the fertilizer cost (FC), transport cost (TC), fertilizer spreading cost (FSC), marginal net return (MNR) and the investment interest (II) during the planting period. The MNR was obtained by multiplying the unit price of the cucumber with the difference between the yield with fertilizer use and yield without fertilizer use. The MNR was obtained as the difference between the GR (gross revenue) and the RCF (revenue cost of fertilizers). The MRR (or PR) was calculated using the following expression:

$$
\mathrm{PR}(\text { or } M R R)=\frac{M N R-R C F}{R C F} \times 100
$$

\section{Results}

\subsection{Petrography}

One rock type outcropped in the study area (granite). The basalt used for treatment was also studied.

\subsubsection{Granite}

The granite is a compact leucocratic rock that outcrops in blocks of various sizes and shapes (Figure 2a). The visible minerals in hand specimen were quartz, feldspars and biotite.

The microscopic structure of the granite is shown in figure $2 \mathrm{~b}$, $\mathrm{c}$ and $\mathrm{d}$. Microcline, about $45 \%$ of the rock, was subhedral with lengths between 0.3-1.2 mm and widths of $0.2-0.9 \mathrm{~mm}$. It showed cross-hatched twins and was greyish white in colour. It was at times perthitic with inclusions of quartz. Plagioclase feldspars (about 12\% of the rock) showed subhedral grains easily identifiable by their polysynthetic twinning. Their mean lengths varied between 0.2-1.8 $\mathrm{mm}$ and width between 0.1-0.7 $\mathrm{mm}$. Orthoclase was rare $(2 \%)$ and subhedral with lengths between $0.2-0.8 \mathrm{~mm}$ and width of $0.2-0.4 \mathrm{~mm}$. Myrmekite was very rare $(<1 \%$ of the rock volume). It was generally localized between quartz and feldspar and was $<0.3 \mathrm{~mm}$ long. Quartz constituted about $30 \%$ of the rock; it was colourless in plane polarized light with a very low relief. It occurred extensively in a massive form, globally $0.2-1.5 \mathrm{~mm}$ long and 0.1-0.8 mm wide. Biotite, made up about $6 \%$ of the rock, with lengths of 0.2-1.5 mm and widths of 0.1-0.3 mm. It occurred as flakes and at times frayed at the extremes (Figure 2d). It was dark brown in plane polarized light with a moderate relief. Muscovite represented about $4 \%$ of the rock. It appeared as flakes at times associated with biotite. It was kinked and more or less oriented.
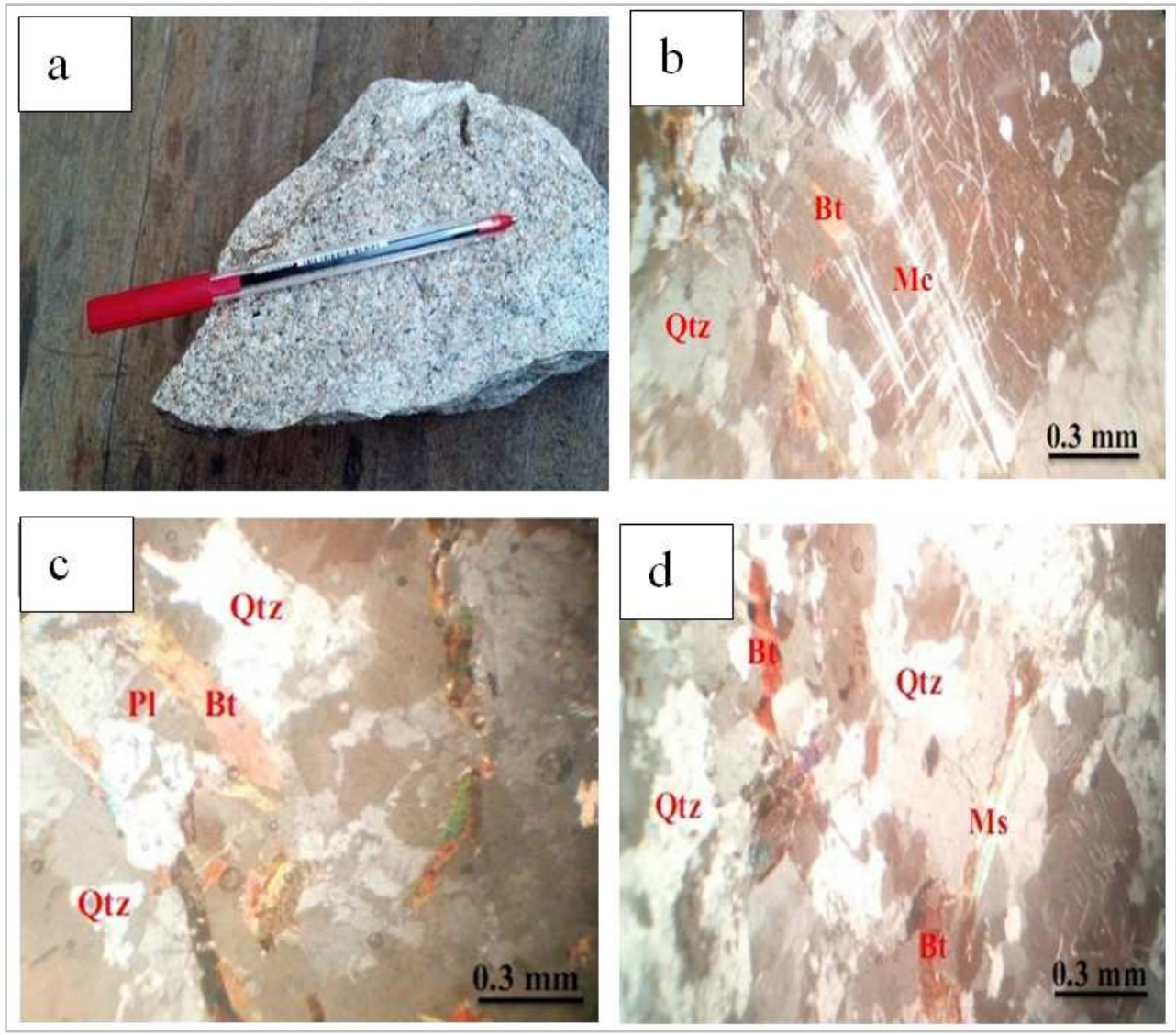

Figure 2. Photographs (a) and photomicrographs (b, $c$ and $d)$ of the granite from Bafut. 

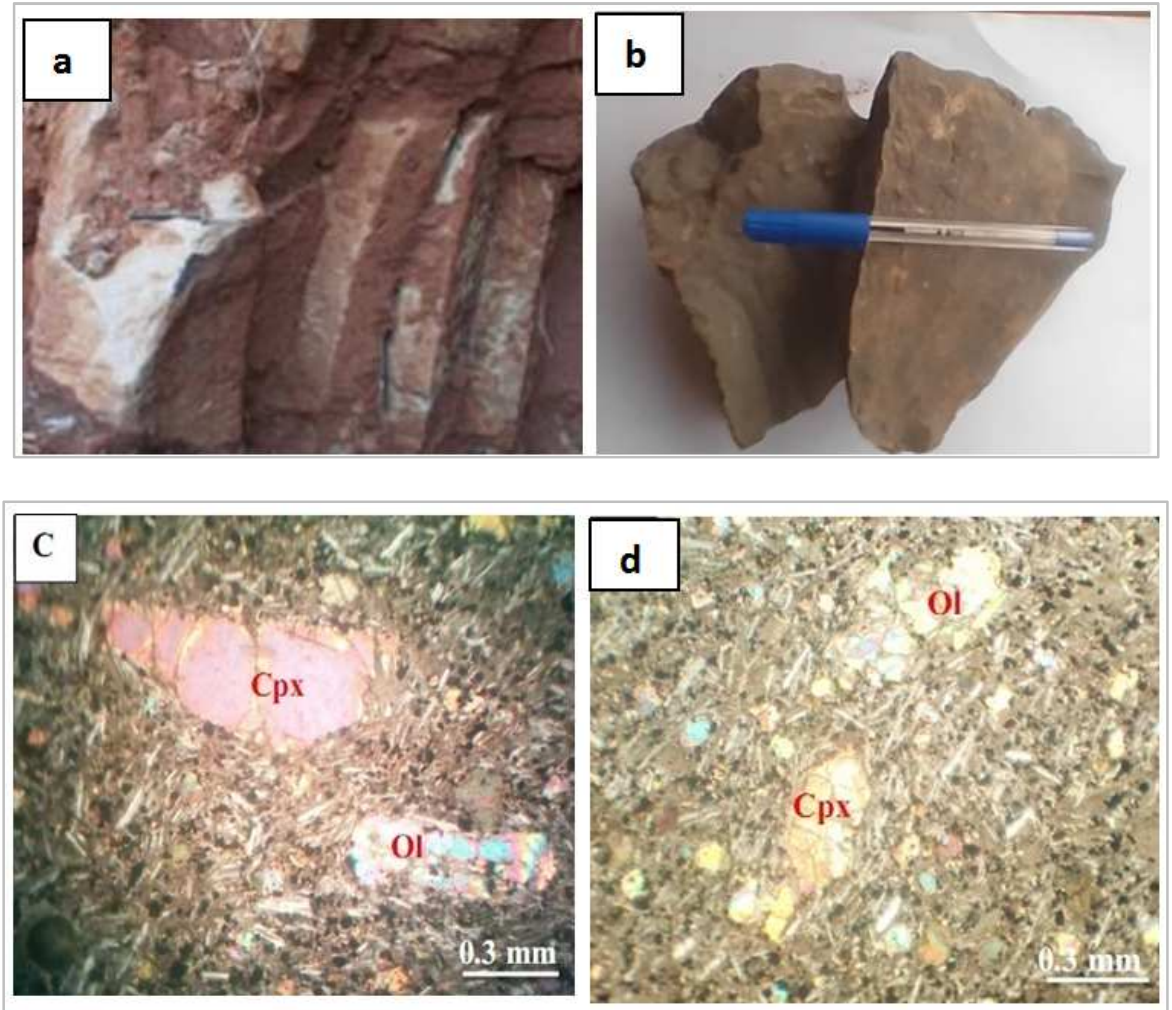

Figure 3. Photographs (A and B) and photomicrographs (C and D) of the basalt used for soil remineralisation.

The dimensions were 0.3 to $3 \mathrm{~mm}$ by 0.1 to $1 \mathrm{~mm}$. It was colourless in plane polarized light with a moderate relief. The mineral association gave a heterogranular texture.

\subsubsection{Basalt}

The basalt outcrop was found in the old Richie quarry of Sabga. It is melanocratic columnar basalts (Figure 3a).

Microscopically, the basalt was composed of olivine, clinopyroxene and rarely plagioclase and an abundant groundmass. Olivine represented about $18 \%$ of the rock. Most of the olivine microphenocrysts showed anhedral to euhedral shapes with cracks. Its lengths varied between 0.2 and $0.7 \mathrm{~mm}$ and widths between 0.1 and $0.5 \mathrm{~mm}$. Under cross polarized light, olivine was bluish pink to light brown (Figure $3 \mathrm{c}$ and d). Clinopyroxene made up about $10 \%$ of the rock, with dimensions of 0.2 to $0.8 \mathrm{~mm}$ by 0.1 to $0.9 \mathrm{~mm}$. They showed microphenocrysts and few phenocrysts, with anhedral to euhedral shapes and a strong relief. Plagioclase represented about $2 \%$ of the total rock volume and was generally corroded. The mineral surfaces exhibited a polysynthetic twin under cross polarized light. Their lengths varied between 0.5 and $0.7 \mathrm{~mm}$ and widths between 0.2 and $0.3 \mathrm{~mm}$. The groundmass constituted about $70 \%$ of the total rock volume and was composed of plagioclase microlites, olivine and clinopyroxene microcrystals, and opaque minerals associated with volcanic glass. The mineral organisation of the basalt resulted to a porphyritic microlitic texture.

\subsection{Soil Characteristics and Land Evaluation}

\subsubsection{Soil Properties}

The control soil was sandy clayey loamy at the surface (0-
$30 \mathrm{~cm})$, acidic $\left(4.0<\mathrm{pH} .{ }_{2} \mathrm{O}<5.3\right)$, with very high organic carbon $(4.63 \%)$, low total nitrogen $(0.2 \%)$, very high $\mathrm{C} / \mathrm{N}$ ratio (23) (Table 1). The sum of bases was very low $(1.84$ cmo $\left.(+) \mathrm{g}^{-1}\right)$ with very low exchangeable $\mathrm{Ca}^{2+}(0.45 \mathrm{cmo}(+)$. $\left.\mathrm{g}^{-1}\right)$ and $\mathrm{Mg}^{2+}\left(0.17 \mathrm{cmo}(+) . \mathrm{g}^{-1}\right)$, high $\mathrm{K}^{+}\left(1.02 \mathrm{cmo}(+) . \mathrm{g}^{-1}\right)$ and low $\mathrm{Na}^{+}\left(0.2 \mathrm{cmo}(+) \mathrm{g}^{-1}\right)$. The CEC was very low $(4.24$ cmo $\left.(+) . \mathrm{g}^{-1}\right)$ and base saturation $(43.4 \%)$ and available phosphorus $\left(16.70 \mathrm{mg} \mathrm{kg}^{-1}\right)$ were moderate.

After treatment, soil $\mathrm{pH}$ increased considerably except for $\mathrm{T}_{3} . \mathrm{T}_{1}$ (6.62), $\mathrm{T}_{2}$ (6.31) and $\mathrm{T}_{4}$ (6.76) showed a moderate acidity whereas $\mathrm{T}_{3}$ still fell in the acidic domain (Table 1). The OC increased and $\mathrm{T}_{2}$ showed the highest levels $(5.15 \%)$ while $\mathrm{T}_{1}, \mathrm{~T}_{3}$ and $\mathrm{T}_{4}$ all had $4.91 \%$ OC. A fabulous increase in TN was observed for $\mathrm{T}_{2}(4.27 \%)$ and $\mathrm{T}_{3}(4.81 \%)$, from $\mathrm{T}_{0}$ $(0.2 \%)$ whereas $\mathrm{T}_{1}$ and $\mathrm{T}_{4}$ each showed very mild increments to $0.23 \%$. The $\mathrm{C} / \mathrm{N}$ ratio values were very high for $\mathrm{T}_{1}(210)$ and $T_{4}(219)$. The $C / N$ values of $T_{2}$ (12) and $T_{3}$ (9) were lower compared to the control, potentially indicating faster mineralization rate. The sum of exchangeable bases for all the treatments was higher than that of $\mathrm{T}_{0}$. However, its levels remained low $\left(4.8 \mathrm{cmo}(+) . \mathrm{g}^{-1}\right)$ for $\mathrm{T}_{3}$, moderate $(6.4 \mathrm{cmo}$ $\left.(+) . \mathrm{g}^{-1}\right)$ for $\mathrm{T}_{2}$ and very low for $\mathrm{T}_{1}$ and $\mathrm{T}_{4}\left(2.2 \mathrm{cmo}(+) \cdot \mathrm{g}^{-1}\right.$ and $2.6 \mathrm{cmo}(+) . \mathrm{g}^{-1}$, respectively). The exchangeable $\mathrm{Ca}$ levels were very low for $\mathrm{T}_{1}\left(1.4 \mathrm{cmo}(+) . \mathrm{g}^{-1}\right), \mathrm{T}_{3}(1.8 \mathrm{cmo}$ $\left.(+) . \mathrm{g}^{-1}\right)$ and $\mathrm{T}_{4}\left(1.6 \mathrm{cmo}(+) . \mathrm{g}^{-1}\right)$ and low $\left(2.04 \mathrm{cmo}(+) . \mathrm{g}^{-1}\right)$ for $\mathrm{T}_{2}$. All the treatments improved the Ca levels of the soils relative to the control. Levels of exchangeable $\mathrm{Mg}$ for all treatments were very low $\left(<0.5 \mathrm{cmo}(+) . \mathrm{g}^{-1}\right)$. The $\mathrm{Mg}$ levels were improved in all the treatment, but $\mathrm{T}_{3}$ showed only a mild improvement relative to the control. Treatments $\mathrm{T}_{1}$ and $\mathrm{T}_{4}$ showed moderate exchangeable $\mathrm{K}$ of $0.31 \mathrm{cmo}(+) . \mathrm{g}^{-1}$ 
each while $\mathrm{T}_{2}$ and $\mathrm{T}_{3}$ revealed low $\mathrm{K}$ values of 0.28 and 0.21 cmo $(+) . \mathrm{g}^{-1}$, respectively. The exchangeable $\mathrm{K}$ of all the treatments was lower than that of $\mathrm{T}_{0}$, but all the values were above the lower limit for crop cultivation after treatment.

Table 1. Soil physico-chemical characteristic before and after treatment.

\begin{tabular}{|c|c|c|c|c|c|c|}
\hline \multicolumn{2}{|l|}{ Soil characteristics } & $\mathbf{T}_{0}$ & $\mathbf{T}_{1}$ & $\mathbf{T}_{2}$ & $\mathbf{T}_{3}$ & $\mathbf{T}_{4}$ \\
\hline \multicolumn{2}{|l|}{ Texture } & Sandy clay loam & Loamy sand & Loamy sand & Loamy sand & Loamy sand \\
\hline \multicolumn{2}{|l|}{$\mathrm{pH}$ water } & 4.50 & 6.62 & 6.31 & 5.50 & 6.76 \\
\hline \multicolumn{2}{|l|}{$\mathrm{OC}(\%)$} & 4.63 & 4.91 & 5.15 & 4.91 & 4.91 \\
\hline \multicolumn{2}{|l|}{$\mathrm{N}(\mathrm{g} / \mathrm{Kg})$} & 0.20 & 0.23 & 4.27 & 4.81 & 0.23 \\
\hline \multicolumn{2}{|l|}{$\mathrm{C} / \mathrm{N}$} & 23.00 & 210.00 & 12.00 & 9.00 & 219.00 \\
\hline \multirow{3}{*}{ Exchangeable bases $\left(\mathrm{cmol}^{(+)} . \mathrm{kg}^{-1}\right)$} & $\mathrm{Ca}^{2+}$ & 0.45 & 1.40 & 2.04 & 1.80 & 1.60 \\
\hline & $\mathrm{Mg}^{2+}$ & 0.17 & 0.45 & 0.42 & 0.22 & 0.46 \\
\hline & $\mathrm{Na}^{+}$ & 0.20 & 0.17 & 0.17 & 0.12 & 0.17 \\
\hline \multicolumn{2}{|l|}{ Sum of exchangeable bases (S) } & 1.84 & 2.20 & 6.40 & 4.80 & 2.60 \\
\hline \multicolumn{2}{|c|}{ Cation exchangeable capacity $\left(\mathrm{cmol}(+) . \mathrm{kg}^{-1}\right.$} & 43.40 & 46.90 & 30.80 & 25.20 & 46.90 \\
\hline \multicolumn{2}{|c|}{ Available phosphorus $(\mathrm{mg} / \mathrm{kg})$} & 16.70 & 67.20 & 50.24 & 84.69 & 68.51 \\
\hline
\end{tabular}

$\mathrm{T}_{0}=$ control soil; $\mathrm{T}_{1}=2.5$ tons ha ${ }^{-1}$ of basalt dust $\mathrm{T}_{2}=20$ tons ha $\mathrm{a}^{-1}$ of poultry manure; $\mathrm{T}_{3}=0.7$ tons ha ${ }^{-1}$ of NPK $20-10-10 ; \mathrm{T}_{4}=5$ tons ha ${ }^{-1}$ of basalt dust

The Na levels were all lower than those of $\mathrm{T}_{0}$, standing at $0.17 \mathrm{cmol}(+) . \mathrm{g}^{-1}$ for $\mathrm{T}_{1}, \mathrm{~T}_{4}$ and $\mathrm{T}_{2}$ and $0.12 \mathrm{cmol}(+) . \mathrm{g}^{-1}$ for $\mathrm{T}_{3}$. The CEC was very low for $\mathrm{T}_{1}\left(4.82 \mathrm{cmol}(+) . \mathrm{g}^{-1}\right)$, low for $\mathrm{T}_{4}\left(5.54 \mathrm{cmol}(+) . \mathrm{g}^{-1}\right)$ and moderate for $\mathrm{T}_{2}(20.78 \mathrm{cmol}(+)$. $\mathrm{g}^{-1}$ and $\mathrm{T}_{3}\left(19.05 \mathrm{cmol}(+) \cdot \mathrm{g}^{-1}\right.$. The base saturation was low in $T_{2}$ and $T_{3}$ whereas $T_{1}$ and $T_{4}$ showed a slight increase enabling to note a moderate base saturation of $46.9 \mathrm{cmol}(+)$. $\mathrm{g}^{-1}$.

\subsubsection{Climatic and Land Characteristics}

The meteorological and land characteristics of the studied area are compiled in Table 2. Thus, IT was 25.12 while ITc was 34.16. This value indicates marginally suitable land class (S3cf) for cucumber cultivation due to soil fertility and climate. The Climatic index (CI) was $53.34(25<53.3492 .5$. The climatic rating (CR) was 48.55 typical of a marginally suitable climate for cucumber cultivation due to precipitation.

\subsection{Plant Growth Parameters}

The plant growth parameters are compiled in Table 3.

The germination rate of the different treatments varied from $53 \%\left(\mathrm{~T}_{0}\right)$ to $97 \%\left(\mathrm{~T}_{2}\right)$. Thus, $\mathrm{T}_{1}, \mathrm{~T}_{2}$ and $\mathrm{T}_{4}$ were above $80 \%$. All treatments were significantly different from one another $(\mathrm{P}<0.05)$, except for $\mathrm{T}_{1}$ and $\mathrm{T}_{2}$ that were not significantly different $(\mathrm{P}>0.05)$ with one another (Table 3$)$.

The number of leaves ranged from 5.9 in $\mathrm{T}_{0}$ (control) to $44.8\left(\mathrm{~T}_{2}\right)$. There was a significant difference $(\mathrm{p} \leq 0.05)$ between $\mathrm{T}_{2}$ and the remaining treatments (Table 3). On weekly basis, $T_{2}$ took the lead to the $13^{\text {th }}$ week with a tremendous peak on the $11^{\text {th }}$ week. On the $15^{\text {th }}$ week, $\mathrm{T}_{4}$ revealed the highest leaf number. $\mathrm{T}_{0}$ showed the least number of leaves from week 3 to week 11, except from $T_{1}$ and $T_{2}$ that were not significantly different $(\mathrm{P}>0.05)$ with each other (Figure 5a).

Table 2. Land and climatic characteristics.

\begin{tabular}{|c|c|c|c|c|}
\hline Land Characteristics & Values & Class & Number of Limitations & parametric Values \\
\hline \multicolumn{5}{|l|}{ Topography (t) } \\
\hline \multicolumn{5}{|l|}{ Wetness (w) } \\
\hline Flooding (i) & $\mathrm{F}_{0}$ & $\mathrm{~S}_{1-0}$ & 0 & 100.00 \\
\hline Drainage (d) & Good & $\mathrm{S}_{1-0}$ & 0 & 100.00 \\
\hline \multicolumn{5}{|l|}{ Soil Physical Characteristics (s) } \\
\hline Texture & SCL & $\mathrm{S}_{1-1}$ & 1 & 95.00 \\
\hline Soil depth (cm) & None & $\mathrm{S}_{1-0}$ & 0 & 100.00 \\
\hline \multicolumn{5}{|l|}{ Soil fertility (f) } \\
\hline Apparent CEC clay (meg/100g) & 12.85 & $\mathrm{~S}_{2}$ & 2 & 80.00 \\
\hline Base Saturation $(\%)$ & 43.40 & $\mathrm{~S}_{1-1}$ & 1 & 86.60 \\
\hline Organic Carbon $(\%)$ & 4.63 & $\mathrm{~S}_{1-0}$ & 0 & 100.00 \\
\hline $\mathrm{pH}$-water & 5.10 & $\mathrm{~S}_{3}$ & 3 & 56.00 \\
\hline \multicolumn{5}{|l|}{ Salinity (n) } \\
\hline Exchangeable Sodium of Percentage (\%) & 4.72 & $\mathrm{~S}_{1-0}$ & 0 . & 97.05 \\
\hline \multicolumn{5}{|l|}{ Climatic characteristics (c) } \\
\hline Length of growing period (days) & 90.00 & $\mathrm{~S}_{1-0}$ & 0 & 100.00 \\
\hline Precipitation of growing period (mm) & 233.30 & $\mathrm{~S}_{3}$ & 3 & 53.34 \\
\hline Temperature mean of the growing period $\left({ }^{\circ} \mathrm{C}\right)$ & 18.53 & $\mathrm{~S}_{3}$ & 3 & 54.70 \\
\hline Relative Humidity of the growing period (\%) & 81.75 & $\mathrm{~S}_{2}$ & 2 & 80.63 \\
\hline \multicolumn{5}{|l|}{ Suitability class } \\
\hline Class & / & $\mathrm{S} 3$ & / & 86.13 \\
\hline
\end{tabular}


Table 3. Means of growth parameters measured in the study. $(n=5)$.

\begin{tabular}{|c|c|c|c|c|c|c|}
\hline $\begin{array}{l}\text { Growth parameters } \\
\text { Treatment }\end{array}$ & $\begin{array}{l}\text { Germination rate } \\
(\%)\end{array}$ & Number of leaves & plant height (cm) & $\begin{array}{l}\text { stem diameter } \\
(\mathrm{cm})\end{array}$ & Leaf length (cm) & $\begin{array}{l}\text { Leaf diameter } \\
(\mathrm{cm})\end{array}$ \\
\hline $\mathrm{T}_{0}$ & $53^{\mathrm{a}}$ & $5.9^{\mathrm{b}}$ & $25.2^{\mathrm{b}}$ & $0.4^{\mathrm{b}}$ & $4.9^{\mathrm{b}}$ & $5.7^{\mathrm{b}}$ \\
\hline $\mathrm{T}_{1}$ & $80^{\mathrm{b}}$ & $8.5^{\mathrm{b}}$ & $32.7^{\mathrm{b}}$ & $0.4^{\mathrm{b}}$ & $6.1^{\mathrm{b}}$ & $6.9^{\mathrm{ab}}$ \\
\hline $\mathrm{T}_{2}$ & $97^{\mathrm{c}}$ & $44.8^{\mathrm{a}}$ & $120.9^{\mathrm{a}}$ & $0.8^{\mathrm{a}}$ & $10.9^{\mathrm{a}}$ & $13.6^{\mathrm{a}}$ \\
\hline $\mathrm{T}_{3}$ & $70^{\mathrm{b}}$ & $11.8^{\mathrm{b}}$ & $52.0^{\mathrm{b}}$ & $0.5^{\mathrm{b}}$ & $7.1^{\mathrm{a}}$ & $7.8^{\mathrm{ab}}$ \\
\hline $\mathrm{T}_{4}$ & $83^{b}$ & $10.8^{\mathrm{b}}$ & $47.8^{\mathrm{b}}$ & $0.4^{\mathrm{b}}$ & $6.8^{\mathrm{a}}$ & $7.7^{\mathrm{ab}}$ \\
\hline
\end{tabular}

The plant height ranged from $25.2\left(\mathrm{~T}_{0}\right)$ to $120.9\left(\mathrm{~T}_{2}\right)$. There was a significant difference $(\mathrm{P} \leq 0.05)$ between $\mathrm{T}_{2}$ and the rest of the treatments (Table 3). $T_{0}$ and $T_{1}$ were also significantly different from $T_{3}$ and $T_{4}$. In the weekly variation of plant height, $T_{2}$ displayed the highest height up to the $11^{\text {th }}$ week meanwhile on the $13^{\text {th }}$ and $15^{\text {th }}$ week, $\mathrm{T}_{4}$ took the lead (Figure $5 \mathrm{~b}$ ).
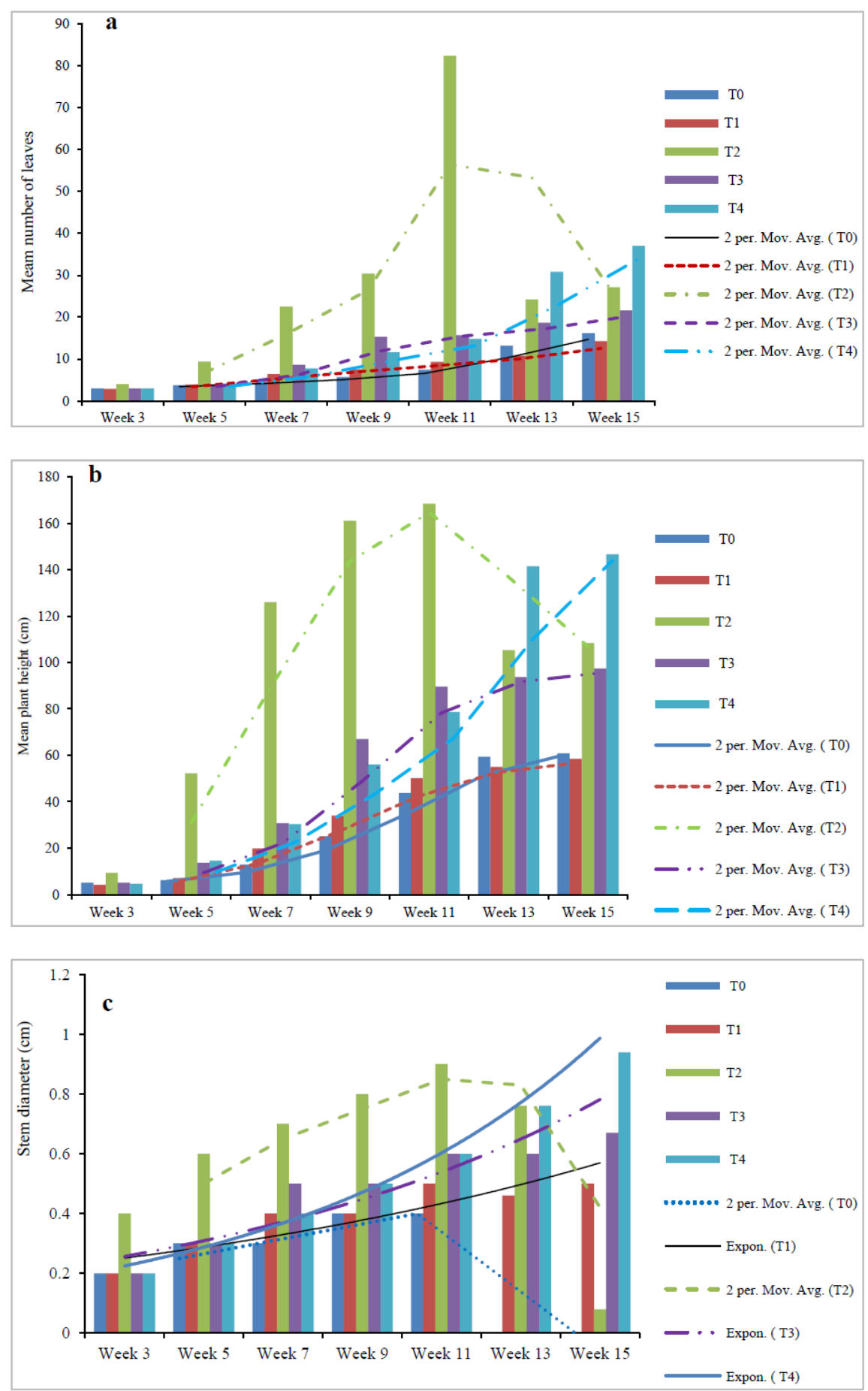

Figure 4. Weekly variation of the number of leaves (a), plant height (b) and stem diameter (c) of cucumber of different treatments $(n=5)$. 
The stem diameter ranged from $0.4 \mathrm{~cm}\left(\mathrm{~T}_{0}\right)$ to $0.8 \mathrm{~cm}\left(\mathrm{~T}_{2}\right)$. There was a significant difference $(P \leq 0.05)$ between $T_{2}$ and the rest of the treatments (Table 3 ). The stem diameter increased progressively for all the treatments with $\mathrm{T}_{2}$ having the largest stem. For the $13^{\text {th }}$ and $15^{\text {th }}$ week, the diameter of
$\mathrm{T}_{0}$ reduced considerably with $\mathrm{T}_{4}$ now being the highest value (Figure 3c).

The leaf length ranged from $4.9 \mathrm{~cm}\left(\mathrm{~T}_{0}\right)$ to $10.9 \mathrm{~cm}\left(\mathrm{~T}_{2}\right)$, with a significant difference $(\mathrm{P} \leq 0.05)$ between $\mathrm{T}_{2}$ and the rest of the treatments (Table 3 ).
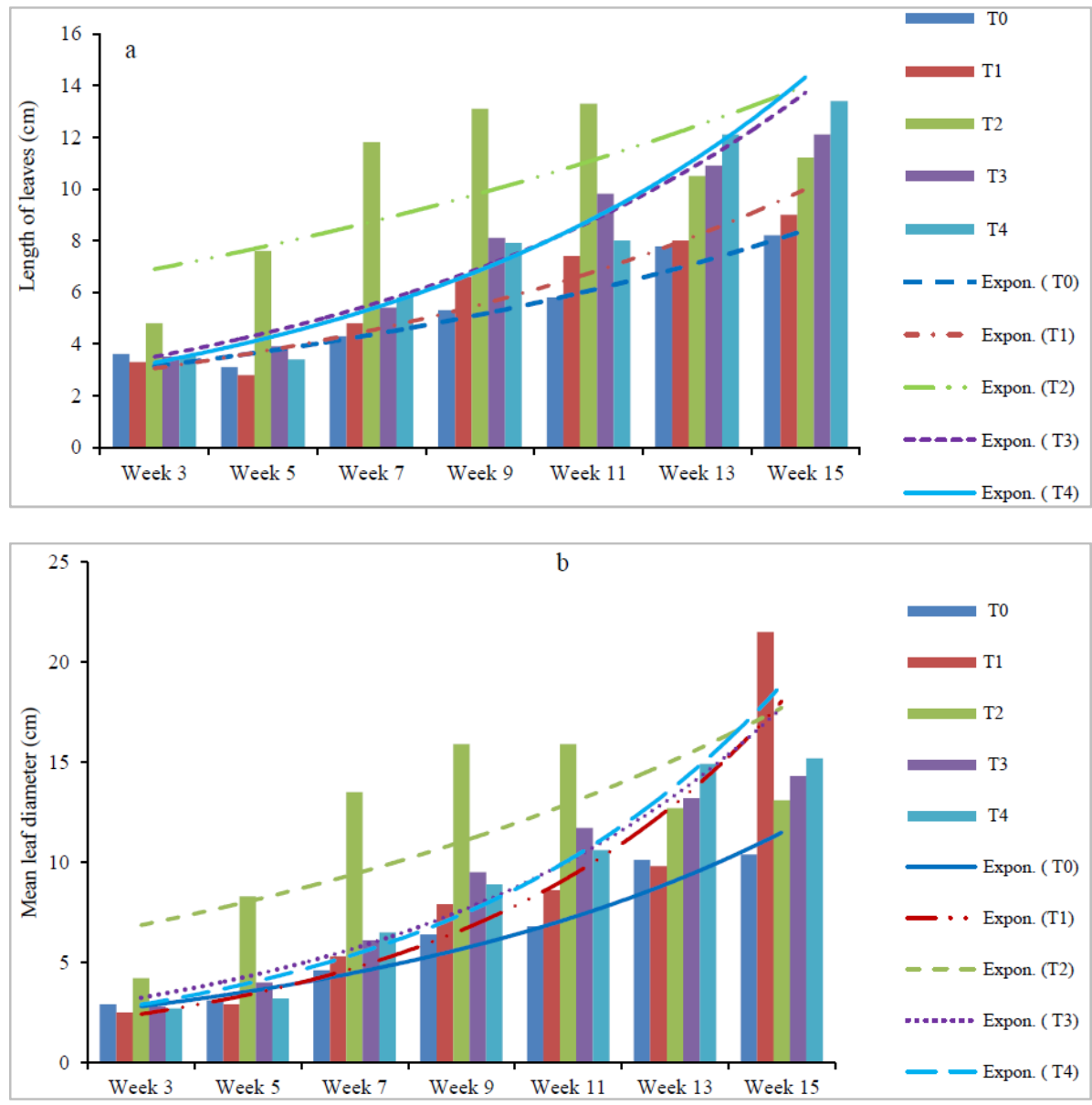

Figure 5. Weekly variation of the leaf length (a) leaf diameter (b) of cucumber per treatment $(n=5)$.

However, the decreasing trend is $\mathrm{T}_{2}>\mathrm{T}_{3}>\mathrm{T}_{4}>\mathrm{T}_{2}>\mathrm{T}_{1}$ (Table 3). There was a progressive increase in the length of the leaves with time; $\mathrm{T}_{2}$ took the lead, but from the $11^{\text {th }}$ week, the growth rate of $\mathrm{T}_{2}$ decreased and $\mathrm{T}_{4}$ now dominated (Figure 6a).

The leaf diameter ranged from $5.7\left(\mathrm{~T}_{0}\right)$ to $12.6 \mathrm{~cm}\left(\mathrm{~T}_{2}\right)$. There was a significant difference $(\mathrm{P} \leq 0.05)$ between $\mathrm{T}_{2}$ and the other treatments (Table 3). There was a perceptible significant increase in leaf diameter for all the treatments with $\mathrm{T}_{2}$ recording the highest value. On the $13^{\text {th }}$ and $15^{\text {th }}$ weeks, $\mathrm{T}_{0}$ showed no further growth, $T_{4}$ recorded the highest leaf diameter in the $13^{\text {th }}$ week and $T_{1}$ in the $15^{\text {th }}$ week (Figure $6 \mathrm{~b}$ ).

\subsection{Yield Parameters}

The mean number of fruits at maturity ranged from $10\left(\mathrm{~T}_{0}\right)$ to $58\left(\mathrm{~T}_{2}\right)$. There was a significant difference $(\mathrm{p} \leq 0.05)$ between treatments. The trend of the number of fruits for the various treatments was as follows: $\mathrm{T}_{2}>\mathrm{T}_{4}>\mathrm{T}_{3}>\mathrm{T}_{1}>\mathrm{T}_{0}$ (Table 4).

Table 4. Means of yield parameters for the different treatments.

\begin{tabular}{lllll}
\hline Treatment & Number of fruits & Fruit length (cm) & Fruit diameter (cm) & Fruit weight (kg) \\
\hline $\mathrm{T}_{0}$ & $10.00^{\mathrm{b}}$ & $2.30^{\mathrm{d}}$ & $0.30^{\mathrm{d}}$ & $2.40^{\mathrm{d}}$ \\
$\mathrm{T}_{1}$ & $19.00^{\mathrm{c}}$ & $4.10^{\mathrm{b}}$ & $0.70^{\mathrm{c}}$ & $5.10^{\mathrm{c}}$ \\
$\mathrm{T}_{2}$ & $58.00^{\mathrm{a}}$ & $14.50^{\mathrm{a}}$ & $4.50^{\mathrm{a}}$ & $57.80^{\mathrm{a}}$ \\
$\mathrm{T}_{3}$ & $22.00^{\mathrm{c}}$ & $5.40^{\mathrm{b}}$ & $1.50^{\mathrm{b}}$ & $11.40^{\mathrm{b}}$ \\
$\mathrm{T}_{4}$ & $26.00^{\mathrm{c}}$ & $5.30^{\mathrm{b}}$ & $1.40^{\mathrm{b}}$ & $6.60^{\mathrm{c}}$ \\
\hline
\end{tabular}

Within the same column, values carrying the same superscript letter are not significantly different at $(\mathrm{p} \leq 0.05)$. 
The mean fruit length ranged from $2.3 \mathrm{~cm}\left(\mathrm{~T}_{0}\right)$ to 13.5 $\left(T_{2}\right)$, with a significant difference $(\mathrm{p} \leq 0.05)$ between $T_{2}$ and the rest of the treatments.

The mean diameter of fruits ranged from $0.3 \mathrm{~cm}\left(\mathrm{~T}_{0}\right)$ to 4.5 $\mathrm{cm}\left(\mathrm{T}_{2}\right)$. There was a significant difference $(\mathrm{P} \leq 0.05)$ between $\mathrm{T}_{2}$ and the other treatments. $\mathrm{T}_{1}, \mathrm{~T}_{3}$ and $\mathrm{T}_{4}$ were not significantly different between themselves but were significantly different with $\mathrm{T}_{0}$. The mean fruits diameter trends as $\mathrm{T}>\mathrm{T}_{3}>\mathrm{T}_{4}>\mathrm{T}_{1}>\mathrm{T}_{0}$ (Table 4).

The mean fruit weight ranged from $2.4 \mathrm{Kg}\left(\mathrm{T}_{0}\right)$ to $57.8 \mathrm{Kg}$ $\left(T_{2}\right)$. There was a significant difference $(p \leq 0.05)$ between $T_{2}$ and other treatments. The average weight of fruits trends as $\mathrm{T}_{2}>\mathrm{T}_{3}>\mathrm{T}_{4}>\mathrm{T}_{1}>\mathrm{T}_{0}$ (Table 4).

The correlation coefficients between all growth and yield parameters are very high, ranging from 0.96 to 0.99 (Table 5).

\subsection{Economic Analysis of Various Treatments}

The economic data of the various treatments is displayed in (Table 6). Thus, $\mathrm{T}_{1}, \mathrm{~T}_{2}$ and $\mathrm{T}_{4}$ were expensive compared to $\mathrm{T}_{3}$. The operation cost (OC) for all the treatments was far below the gross return (GR) implying a positive outcome for all the treatments. The highest GR was observed in $\mathrm{T}_{2}$. Compared to $\mathrm{T} 0$, the others treatments $\left(\mathrm{T}_{1}, \mathrm{~T}_{3}, \mathrm{~T}_{4}\right)$ were profitable. Based on the value-to-cost ratio $(\mathrm{VCR})$, only $\mathrm{T}_{1}(\mathrm{VCR}=10.3)$ and $\mathrm{T}_{2}$ $(\mathrm{VCR}=5.8)$ with values $>2$ can be popularised.

Table 5. Correlation coefficients between growth and yield parameters of Beetroot ( $n=5)$.

\begin{tabular}{|c|c|c|c|c|c|}
\hline & Number of leaves & Plant height & Stem Diameter & Leaf length & Leaf diameter \\
\hline Number of fruits & 0.97 & 0.98 & 0.93 & 0.99 & 0.99 \\
\hline Fruit length & 0.99 & 0.99 & 0.96 & 0.99 & 0.99 \\
\hline Fruit diameter & 0.98 & 0.99 & 0.96 & 0.99 & 0.99 \\
\hline
\end{tabular}

Table 6. Economic value of cucumber per treatment.

\begin{tabular}{|c|c|c|c|c|c|c|c|}
\hline Treatments & AY (Kg/ha) & EY (Kg/ha) & GR (FCFA) & FC (FCFA) & TEEY (FCFA) & FSC (FCFA) & FTC (FCFA) \\
\hline T0 & 1476 & 0 & 738250 & 0 & 0 & 0 & 0 \\
\hline $\mathrm{T} 1$ & 3121.6 & 1645.6 & 1560800.0 & 509259.3 & 74074.1 & 35000.00 & 23148.00 \\
\hline $\mathrm{T} 2$ & 35693.8 & 34217.3 & 17846900.0 & 1400000.0 & 74074.1 & 35000.0 & 80000.0 \\
\hline T3 & 7042.0 & 5565.5 & 3521000.0 & 350000.0 & 74074.1 & 35000.0 & 2800.0 \\
\hline $\mathrm{T} 4$ & 4079.0 & 2602.5 & 2039500.0 & 1018518.5 & 74074.1 & 35000.0 & 46296.3 \\
\hline
\end{tabular}

Table 6. Coutinued.

\begin{tabular}{llllllll}
\hline Treatments & OC (FCFA) & II (FCFA) & RCF (FCFA) & MNR (FCFA) & VCR & NR (FCFA) & PR (\%) \\
\hline T0 & 0 & 0 & 0 & 0 & 0 & 0 \\
T1 & 641481.40 & 27262.90 & 668744.40 & 822800.00 & 1.20 & 892055.60 \\
T2 & 1589074.1 & 67535.7 & 1656609.8 & 17108650.0 & 10.3 & 22.00 \\
T3 & 461874.1 & 19629.6 & 481503.7 & 2782750.0 & 5.8 & 16190290.2 \\
T4 & 1173888.9 & 49890.3 & 1223779.2 & 1301250.0 & 1.1 & 3039496.3 & 480.0 \\
\hline
\end{tabular}

AY: Average yield; GR: Gross return; EY: Extra yield; FC: Fertilizer cost; TEEY: Total expenditure on extra yield; FSC: Fertilizer spreading cost; FTC: Fertilizer transport cost; OC: Total cost; II: Interest on investment (4.25\% per annum in Cameroon); RCF: Revenue cost of fertilizers; MNR: Marginal net return; VCR: value-to-cost ratio; NR: net return; PR (\%): Profit rate (due to soil treatment); FCFA: Francs French Currency in Africa; Cost of cucumber in the market $\approx 500 \mathrm{FCFA} / \mathrm{kg}$.

\section{Discussion}

\subsection{Effects of Treatments on Soil Properties}

All the treatments led to a slight increase in $\mathrm{pH}$; the $\mathrm{pH}$ values of $T_{1}, T_{2}$ and $T_{4}$ fell between 5.5 and 7.5, the optimum range for cucumber cultivation [23, 27]. This indicates that the various treatments reduced the acidity of the soil to a meaninful level. This $\mathrm{pH}$ rise has a positive impact on other soil physico-chemical properties as base saturation, cationic balance and microbial activity [28, 29]. According to [13], the studied basalt has silica content between 48.68 and $45.60 \% \mathrm{SiO}_{2}$, typical of basic rocks. This could also justify the increase in soil $\mathrm{pH}$ following basalt application. The exchangeable $\mathrm{Ca}$ and $\mathrm{Mg}$ increased after harvest whereas exchangeable $\mathrm{Na}$ and $\mathrm{K}$ decreased for all treatments. Similar results have already been reported by [30], probably implying that exchangeable $\mathrm{K}$ and $\mathrm{Na}$ might have been taken up by the plant. $\mathrm{T}_{2}$ showed the highest transfer of exchangeable $\mathrm{Ca}$ and $\mathrm{Mg}$ from poultry manure to the soils. This could explain why $\mathrm{T}_{2}$ produced the best cucumber yield amongst all the treatments.

\subsection{Effect of Treatments on Crop Performance}

The different treatments displayed unlike effects on the growth parameters of cucumber $\mathrm{T}_{2}>\mathrm{T}_{3}>\mathrm{T}_{4}>\mathrm{T}_{1}>\mathrm{T}_{0}$. For yield parameters, number of fruits from all the treatments were such that $\mathrm{T}_{2}>\mathrm{T}_{4}>\mathrm{T}_{3}>\mathrm{T}_{1}>\mathrm{T}_{0}$. Also, trend of mean fruit length, mean fruit diameter and mean fruit weight was $T_{2}>T_{3}>T_{4}>T_{1}>T_{0}$. There was a significant difference between $\mathrm{T}_{2}$ and the other treatments. The reason for $\mathrm{T}_{2}$ taking the lead could be linked to the highly available phosphorus and 
nitrogen in poultry manure which favoured plant growth [27]. Potassium helps in water uptake and protein synthesis by plants; calcium improves tissue integrity, functions in structure and permeability; magnesium reduces soil acidity and activates plants enzymes for growth; phosphorus stimulates early growth and hastens maturity [31]. This might have accounted for the highest yield in $T_{2}$ [30]. Poultry manure with a slightly alkaline $\mathrm{pH}$, was able to neutralise the soil acidity and to make available the soil nutrients as total nitrogen, exchangeable cations $(\mathrm{Ca}, \mathrm{K}$ and $\mathrm{Mg})$ and phosphorus. $\mathrm{T}_{3}$ was close to $\mathrm{T}_{2}$ in terms of growth and yield performance, except in terms number of fruits, as nitrogen fertilizer is an essential component of the chlorophyll molecule and protein synthesis [32]. This is capable of promoting photosynthesis and sprout of leaves. Cucumber treated with basalt showed a significant growth rate after the $13^{\text {th }}$ week indicating that the basalt dust needed more time to weather for nutrients release into the soil and subsequent assimilation by plants. This agrees with [10] whereby after the first month of carrot growth, stem heights showed comparable values with control soil in almost all treatments suggesting no release of nutrients in the soils before the first month of growth. The time of rock application might thus be short and it is possible that yields could increase following subsequent planting seasons with the residual effect of the fertilizer. This agrees with [33] whose rock dust trials on plants showed significant results five times higher after a few years of application. Basalt dust containing high proportions of olivine, pyroxene and amphiboles show natural weathering rates [34]. The petrographic analysis of the basalt dust showed a high proportion of olivine which might have contributed some $\mathrm{Ca}, \mathrm{Mg}$ and trace elements upon weathering. The major initial problem of the soil was that of acidity but after basalt treatment, there was an improvement in soil acidity from 4.5 in $\mathrm{T}_{0}$ to 6.62 in $\mathrm{T}_{1}, 6.31$ in $\mathrm{T}_{2}$ and 6.76 in $\mathrm{T}_{4}$. Gillman [35] documented that basalt dust slowly increases soil $\mathrm{pH}$ just as lime, except over a longer period of time, but generates less stress on plant growth. The nutrients released by rock dust are directly related to weathering, thus, their beneficial effect could last for many years before needing replacement and even longer if used in conjunction with sustainable farming techniques [36-38]. The control soil showed the lowest yield because the soil was very acidic. Under such low $\mathrm{pH}$ conditions, the availability of nitrogen, phosphorus and exchangeable cations are compromised [39, 40]. Consequently in $\mathrm{T}_{0}$, nitrogen is low and organic matter is of very poor quality $(\mathrm{C} / \mathrm{N}=23)$ potentially indicating very slow mineralization. Also, the sum of exchangeable bases was very low with very low exchangeable $\mathrm{Ca}$ and $\mathrm{Mg}$ ' high exchangeable $\mathrm{K}$ and low exchangeable $\mathrm{Na}$.

The fact that all the growth parameters were significantly correlated with yield parameters $(0.96<\mathrm{r}<0.99)$ implies that any factor that promotes growth of cucumber is susceptible to enhance high yield.

\subsection{Economic Outcomes of the Treatments}

$\mathrm{T}_{1}, \mathrm{~T}_{2}, \mathrm{~T}_{3}$ and $\mathrm{T}_{4}$ were all expected to be profitable as their VCR $>1$ [27]. The most economically viable treatments in terms of yield were attained by $\mathrm{T}_{2}$ with a profit rate of $933 \%$ and a VCR value of 10.3 and $\mathrm{T}_{3}$ with a profit rate of $480 \%$ and a VCR value of 5.8. According to [27], a $\mathrm{VCR} \geq 2$ implies a recovery of at least $100 \%$ of the investments from the yields. From the economic evaluation, poultry manure and NPK 20-10-10 can be popularized for the cultivation of cucumber. The results of basalt treatment $\left(T_{1}\right)$ contradict those of [41] whereby addition of rock dust has no observable effects on yields.

\section{Conclusion}

The present work compared the effects of basalt dust, poultry manure and NPK 20-10-10, combined and single, on soil fertility and cucumber output. Principal results revealed that the control soil $\left(\mathrm{T}_{0}\right)$ was very acidic, with low nitrogen, moderate available phosphorus, high $\mathrm{K}$, very low $\mathrm{Ca}$ and $\mathrm{Mg}$ ' low $\mathrm{Na}$ ' very low sum of bases, very low cation exchange capacity and a moderate base saturation. The $\mathrm{C} / \mathrm{N}$ ratio was very high $(>20)$ indicating poor quality organic matter and slow mineralization rate. After treatments, $\mathrm{pH}$, exchangeable $\mathrm{Ca}$ and $\mathrm{Mg}$ increased whereas exchangeable $\mathrm{Na}$ and $\mathrm{K}$ decreased. Growth and yield of all treatments, except number of fruits, was such that $\mathrm{T}_{2}>\mathrm{T}_{3}>\mathrm{T}_{4}>\mathrm{T}_{1}>\mathrm{T}_{0}$. The numbers of fruits were as follows: $\mathrm{T}_{2}>\mathrm{T}_{4}>\mathrm{T}_{3}>\mathrm{T}_{1}>\mathrm{T}_{0}$. Economically, treatments $\mathrm{T}_{1}, \mathrm{~T}_{2}, \mathrm{~T}_{3}$ and $\mathrm{T}_{4}$ were profitable with a $\mathrm{VCR}>1$, but $\mathrm{T}_{2}\left(20\right.$ tons ha ${ }^{-1}$ of poultry manure) and T3 (0.7 tons ha ${ }^{-1}$ of NPK 20-10-10) showed a $\mathrm{VCR}>2$ and are recommendable for popularization.

\section{Conflict of Interests}

The authors declare no conflict of interests.

\section{References}

[1] Thompkins, P. and C. Bird (1989) Secrets of the soils. Penguin Books, London.

[2] Diver, S. (1998). Rock dust in agriculture: Insights on Remineralisation and paramagnetism. Appropriate Technology Transfer for Royal Areas, London.

[3] Yeomans, A. J. (2005). Together we can Beat Global Warming. Sydney, Keyline Publishing limited (www.yeomansplow.com.au). 492 P.

[4] Hamaker, J. D. and D. Weaver (1982). The survival of civilization. Hamaker-Weaver publication, MichiganCalifornia, USA. 219p.

[5] Leidig, G. (1993). Rock dust and microbial action in soil: the symbiotic relationship between composting and mineral additives. Remineralize the Earth 4-5, 12-14.

[6] Campe, J. (1995) Pot tests with rock dust for corn. Remineralize the Earth 37, 7-8.

[7] Alanna, M. (2001) Stone Age Farming: Eco-agriculture for the 21 st Century. Queensland, Python Press, 213p.

[8] Nganfi, F. (1997) Amélioration des conditions physico-chimiques et la fertilité des sols par l'utilisation directe de certaines roches. Mémoire. Maitrise, Université de Dschang, 67p. 
[9] Nkouathio, D. G., P. Wandji, J. M. Bardintzeff, P. Tematio, D. A. Kagou and F. M. Tchoua (2008) Utilisation des roches volcaniques pour la reminéralisation des sols ferrallitiques des régions tropicales. Cas des pyroclastites basaltiques du graben de Tombel (Ligne volcanique du Cameroun). Bulletin de la Société Vaudoise des Sciences Naturelles, 91 (1), 1-14.

[10] Tetsopgang, S., P. Kamga, F. Paul, A. Gonang, B. Alemanji, D. Z. Manjo and L. Mazoh (2014) Effect of Powders of Basalts, Tuff, Granites, and Pyroclastic Materials on Yield and Quality of Carrots and Cabbages Grown on Tropical Soils in the Northwest Region of Cameroon. Geotherapy 25, 435-443.

[11] Fotsa, T. J. M. (2015). Effect of basalt, granite and gneiss, associated to Tithonia diversifolia (sunflower) on growth of Okra (Abelmoschus esculentus) in Bamougoum (West Region, Cameroon). Master thesis, University of Bamenda, 58p.

[12] Tchouankoue, J. P., T. A. N. Tetchou, A. M. Abossolo, C. Ngansop and T. S. Huff (2015). Rock fertilizers as an alternative to conventional fertilizers: The use of basalt from the Cameroon Volcanic Line for maize farming on ferralitic soils. Geotherapy 26, 445-458.

[13] Kamgang, P., G. Chazot, E. Njonfang, N. N. B. Tchuimegnie and F. M. Tchoua (2013). Mantle sources and magma evolution beneath the Cameroon Volcanic Line: Geochemistry of mafic rocks from the Bamenda Mountains (NW Cameroon). Gondwana Research 24, 727-741.

[14] Etia, P. M. (1980). Climate and Climatic Zones of Cameroon. In: JA, Ed., Les Atlas Jeune Afrique, Paris, France, p.16-19.

[15] Acho-Chi, C. (1998). Human interference and environmental instability addressing consequences of rapid urban growth in Bamenda. Environment and Urbanization 10 (2), 161-174.

[16] Azinwi Tamfuh, P., D. Tsozué, M. A. Tita, Boukong, A., R. T. Ngnipa, H. T. Ntangmo and A. D. Mvondo Ze (2017). Effect of Topographic Position and Seasons on the Micronutrient Levels in Soils and Grown Huckleberry (Solanum scabrum) in Bafut (North-West Cameroon). World Journal of Agricultural Research 5 (2), 73-87.

[17] Van Reeuwijk, L. (2002). Procedures for soil analysis. $6^{\text {th }}$ edition, ISRIC, FAO, Wageningen.

[18] Walkley, A. and I. A. Black (1934). Determination of organic matter in soil. Soil Science 37, 549-556.

[19] Bremner, J. M. and C. S Mulvaney (1982). Total Nitrogen. In: Buxton, D. R., ed., Methods of soil analysis, Part 2. American Society of Agronomy Inc. and SSSA Inc, Madison, USA.

[20] Olsen, S. R. and L. E. Sommers (1982). Phosphorus. In: Page AL, Buxton RH, Miller Keeney DR, Editors. Methods of soil analysis. American Society of Agronomy Madison, 403-430p.

[21] Thomas, G. W. (1982). Exchangeable cations. In: Page AL, Buxton RH, Miller Keeney DR, Editors. Methods of soil analysis. American Society of Agronomy, Madison, 159-165p.

[22] Rhoades, J. D., (1982). Cation exchange capacity. In: Page AL, Buxton RH, D. R. Miller Keeney, Eds., Methods of soil analysis. American Society of Agronomy, Madison, 149-158p.

[23] Beernaert, F. and D. Bitondo (1993). Land evaluation manual. Dschang University Centre, Dschang.

[24] Khiddir, S. M. (1986). A statistical approach in the use of parametric systems applied to the FAO Framework for land evaluation. Ph.D. Thesis, State University of Ghent, Ghent.

[25] Beernaert, F. and D. Bitondo (1991). Simple and Practical Methods to Evaluate Analytical Data of Soil Profiles. Belgian Cooperation University of Dschang, Dschang.

[26] FAO (1990). The design of agricultural investment projectsLessons from experience. Technical paper no. 5. Investment Centre, FAO, Rome.

[27] Tankou, C. B. (1996). Vegetable crops. University of Dschang, Dschang.

[28] Sarker, M. S. (2005). Effect of different levels of nitrogen and phosphorus on yield quality of radish. Master's thesis, Agriculture University of Bangladesh, Bangladesh.

[29] Low, R. (2017). Gardening tips using rock dust as a fertilizer. CanAmaze Volcanic Rock Dust Rock Powder. https://canamaze.com/gardening-tips-using-rock-dustfertilizer/. Accessed on 9/11/2019 at 7.30pm

[30] Asongwe, G. A., B. K., Yerima and A. S. Tening (2015). Spatial variability of selected physico-chemical properties of soils under vegetable cultivation in urban and peri-urban wetland gardens of Bamenda municipality, Cameroon. African Journal of Agricultural Research 11 (2), 74-86p. DOI: 15.5897/AJAR2015.10401

[31] Yerima, B. P. K. and E., Van Ranst (2005). Soils of Cameroon: distribution, genesis, characteristic, management and utilization. Publishing Victoria B. C., Trafford.

[32] Tisdale, S. L. and W. L. Nelson, J. D. Beaton (1985). Soil fertility and fertilizer, $4^{\text {th }}$ ed. Macmillan, New York, 249-291.

[33] Sauter, V. U. and K. Forest (1987). Information for the application of silicate dust for the amelioration of forest soils. Bavarian Research Institute Journal 2, 27-30.

[34] Goldich, S. S. (1938). A study of rock weathering. Journal of Geology 46, 17-58.

[35] Gillman, G. P., D. C. Buekkett and J. R. Coventry (2002). Amending highly weathered soils with finely ground basalt rock. Applied Geochemistry 17, 987-1001.

[36] Van Straaten, P. (2002). Rocks for crops: agrominerals of subSaharan Africa. ICRAF, Nairobi.

[37] Van Straaten, P. (2017). Rocks for crops in the world. Remineralize the earth. Organic Gardening Resource Centre. Website: www.groworganic.com. Accessed on 08/11/2019 at $7.15 \mathrm{pm}$.

[38] Wotchoko, P., C. S. Guedjeo, H. Mbouobda, G. Ngnoupeck, Z. Itiga, Y. A. B. Nwobiwo, D. G. Nkouathio, A. and A. D Kagou (2016). Remineralisation of tropical ferralitic soils using volcanic rock (tephra) powder in the fertilization of Bambili soils, experimented on Zea mays, Cameroon. International Journal of Development Research 6 (04), 75527556.

[39] Silva, J. A. and R. S. Uchida (2000). Plant nutrient management in Hawaii's soils: Approaches for tropical and subtropical agriculture. College of Tropical Agriculture and Human Resources, University of Hawaii at Monoa, Honulu, 4-151p.

[40] Leonardos, O. H., W. S. Fyfe and B. I. Kronberg (1987). The use of ground rocks in laterite systems: An improvement in the use of conventional soluble fertilizers? Chemical Geology 60, 361-370. 
[41] Ramezanian, A., A. S. Dablin, C. B. Campbell, S. Hillier, B. Mannerstedt-Fogelfors, I. Öborn (2013). Addition of a volcanic rock dust to soils has no observable effects on yield and nutrient status or soil microbial activity. In: Walter, T. W and J. K. Syer (Eds), Pedogenesis, nutrient dynamics and ecosystem development and Soil, Vol. 367 (1-2), part 1, Plant and Soil: New York, pp. 419-436. 